\title{
THE PRESENT STATUS OF MAITLAND'S "EQUITY"
}

\author{
G. H. STEER*
}

Maitland's view of the place of Equity in English law is to be found in the 1910 Edition of his Course of Lectures' where he considers the effect of the Judicature Acts of $1873^{2}$ and $1875 .^{3}$ He regarded equity as:

... supplementary law, a sort of appendix added on to our code, or a sort of gloss written round our code, an appendix, a gloss which used to be administered by courts specially designed for that purpose but which is now administered by the High Court of Justice as part of the code. The language which equity held to common law if we may personify the two was not 'No, that is not so, you make a mistake your rule is an absurd an obsolete one'; but 'yes, of course that is so but it is not the whole truth. You say that $A$ is the owner of the land but I must add that he is bound by one of those obligations known as trusts."

The master then points out that equity and common law should not be regarded as rival systems, but that equity presupposes the existence of the common law and, unlike it, is incapable of exposition as a self sufficient system. It is nothing but a collection of appendices to the rules of common law relating to torts, in a minor, and to contracts and property, in a major, degree, e.g. the granting of injunctions, the declaration of trusts, the specific performance, rectification, and cancellation of contracts, the redemption of mortgaged property and relief against penalties and forfeitures. All these appendices were bound together under the head of "Equity" by a jurisdictional and procedural bond. They were within the cognizance only of courts of equity.

Then came the Judicature Acts of 1873 and 1875 which broke the bond by providing that a judge of the High Court of Justice, no matter to which of the Divisions of the Court he might belong, was bound to administer the law, whether rules of common law or equity, in all cases that came before him. The statute of 1873 also contained the familiar Subsection 11 of Section 25 to the effect that:

Generally in all matters not hereinbefore particularly mentioned in which there is any conflict between the rules of equity and the rules of common law, the rules of equity shall prevail." that:

Maitland sums up his discussion of the Judicature Acts by saying

The day will come when lawyers will cease to inquire whether a given rule be a rule of equity or a rule of common law; suffice it that it is a well established rule administered by the High Court of Justice."

A word must now be said about the development of the rules of equity subsequent to 1873 . There is little doubt but that in their origin they were rules which depended on the view of the Chancellor of the day as to what in the circumstances was right, just and conscientious conduct on the part of the respondent against whom a bill was presented in equity. It is the respondent's conscience that must be measured

\footnotetext{
- George Hobson Steer, Q.C., M.A. (Queen's). LL.D. (Alta.), LLD. (Queen's) of the Alberta, Britlsh Columbla and Yukon Territory Bars.

1 Maltland. Equity, a course of lectures 15-20 (1st ed. 1910).

$236 \& 37$ Vietorla, c. 66.

J 3839 Victorla, c. 77 .

- Id. ot 18.

- See the Alberta Judicature Act, R.8.A. 1955, c. 164, a. 34, s. 513.

- Op. Cit. supra. at 20.
} 
against that of the Chancellor and at all times there must be borne in mind the emphasis placed on the maxim that equity acts in personam. Nor is there doubt that in giving effect in the earliest times to what according to his view was such conscientious, right and just conduct on the part of the respondent the Chancellor had the power to correct the common law and to abate its rigour.

\section{Holdsworth's History' reads:}

In early days there were no fixed principles upon which the Chancellors exercised their equitable jurisdiction. The rule applied depended very much upon the ideas as to right and wrong possessed by each Chancellor. Hence there is a considerable amount of truth in Selden's well-known aphorism. Equity is a roguish thing. For law we have a measure ... equity is according to the conscience of him that is Chancellor, and as that is larger or narrower, so is equity. 'Tis all one as if they should make the standard for the measure a Chancellor foot.' But in the latter half of the seventeenth century it is clear that the principles of equity were beginning to gain in fixity. Cases decided in the court of Chancery were beginning to be reported, and those cases were clted as authorities and followed. This tendency increased in strength throughout the eighteenth century. The Chancellors themselves admitted that, though they had a discretion, this discretion ought to be exercised in accordance with precedent. Lord Hardwicke, though he claimed for the Chancellor a discretion to judge according to the circumstances-otherwise there might arise a claim for equitable relief even against decrees in equity-distinctly stated that general rules were absolutely necessary to guide the judge's discretion.

Blackstone in his Commentaries ${ }^{8}$ disputes the power of Courts of Equity to abate the rigours of the common law and points to hard cases at law which the Chancellor did nothing to remedy; but as pointed out by Pomeroy ${ }^{\ominus}$ the fact that the Chancellor refrained from action in the cases mentioned is not to deny his power to do so. But the jurisdiction to grant relief first by the King and later by the Chancellor according to conscience, even by the last quarter of the seventeenth century became limited by rules ultimately as fixed, or almost so, as those of the common law.

The growth of the idea that fixed rules were as essential to the proper administration of equity as they were to that of the common law may be traced in:

(i) the statement of Lord Chancellor Nottingham in Cook v. Fountain ${ }^{10}$ that:

... .with such a conscience as is only naturalis and interna this court has nothing to do; the conscience by which I am to proceed is merely civilis and politica and tied to certain measures.

(ii) the stated inability of Lord Hardwicke in Trelawney v. Booth ${ }^{21}$ to give effect to his conception of the justice of the case before him because of settled rules on the doctrine of conversion. ${ }^{12}$

(iii) two statements of Lord Eldon in 1818, the first in Davis v. The Duke of Marlborough ${ }^{13}$ that:

7 Holdsworth, History of Engltsh Law Vol. I, 467-8 (3rd. ed. 1923).

8 3 Blackstone, Commentarles 430.

- Pomeroy, Equity Jurisprudence 56 (3rd. ed. 1905).

103 Swans. 586, 600, 36 E.R. 984, 990.

112 Atk. 308, 26 E.R. 588.

12 For a general description of Lord Hardwlcke's contrlbution to equity doctrine and his adherence to precedent in its development during the perfod of his Chancellorshlp (1737-1756) reference may be made to Holdsworth's History, Vol. XII. 258-85.

132 Swans. 108, 163, 36 E.R. 555, 568. 
It is not the duty of a judge in Equity to vary rules or to say that rules are not to be considered as fully settled here as in a court of law.

and the second in Gee v. Pritchard"14 that:

... the doctrines of this court ought to be as well settled and made as uniform almost as those of the common law laying down fixed principles but taking care that they are to be applied according to the circumstances of each case. I cannot agree that the doctrines of this court are to be changed with every succeeding judge. Nothing would inflict on me greater pain in quitting this place than the recollection that I had done anything to justify the reproach that the equity of this court varies like the Chancellor's foot.

(iv) the decision of Sir George Jessel, M.R., a judge in Equity both before and after the. Judicature Act, in the case of Johnson v. Crook $^{10}$ where dealing with a will which was before him he said that the only question he had to decide was whether the law would permit effect to be given to the will, that there was no statute law or common law to prevent it and that "If there is anything to prevent it it must be found in some law manufactured by the Judges in the equity Jurisdiction."

The will provided that on the death of a legatee "before he shall have actually received his share of the residue without leaving issue" his share should go over to the other legatee of the residue. After a discussion of a number of cases in which similar clauses were given effect, the judge referred ${ }^{10}$ to a decision of $1866^{17}$ contrary to the ones he had previously discussed, and in the course of giving his reasons for refusing to follow it he said:

Now it [the rule of law relied on prohibiting effect being given to such a clause] could only have been made in the year 1866 by statute because in the year 1866 Equity Judges did not profess to make new law and when they state what the law is they do not mean, es might have been said two or three centuries before, that that was law which they thought ought to be law.

Again he said:

All I can say about it is, being clearly of opinion that the Vice-Chancellor did not arrogate to himself in 1866 legislative powers, and there being no statute, and there being no prior cases which say law will not allow it, but there being a great many prior cases saying the law will if it is clearly expressed. that it was simply a mistake of the Vice-Chancellor, and that is how I shall treat it. It is only in 1866, and all the authorities are the other way, and there being neither statute nor common law to be cited against it, the statement that the law will not allow it must have been made per incuriam.18

(v) the opinion of Lord Greene in Diplock's Case ${ }^{20}$ where he expressed the same view in saying:

Nevertheless if the claim in equity exists it must be shown to have an ancestry founded in history and in the practice and precedents of the courts administering equity jurisdiction. It is not sufficient that because we may think that the 'justice' of the present case requires it we should invent such a jurisdiction for the first time ${ }^{20}$

An article, Precedent in Equity, in the Law Quarterly Review 21 leads to the same conclusion so that it appears clear that what happened in equity bears a striking similarity to what had happened in the common

242 Swans. $403,414,36$ E.R. 670, 674.

1612 Ch. D. 639. 642

26 Id. at 649 . Martin L.R. 2 Ea. 404.

18 Stpre, n. 15 , at 650

10 In Re Diplock [1948] Ch. 465, 481-2.

20 Upheld [1951] A.C. 251. Sce at 276 where views of the binding effect of equity 31 Winder (1941) 57 I.Q.R. 
law. In both jurisdictions an early element of discretion ultimately disappeared as the importance of certainty in the law was realized, a certainty which in each case was achieved by adherence to .precedent, and it seems clear that at the date of the enactment of the Judicature Acts the power of judges to enunciate new equitable principles had ceased.

There is little doubt that judges may regret from time to time that their equitable jurisdiction has been thus hedged about by precedent, and that before effect can be given to their personal views of what justice requires they must find, to repeat Lord Greene's words, support "in history and in the practice and precedents of the courts".22

Such a problem was undoubtedly present to Denning, J., ${ }^{22 a}$ as he then was, in Central London Property Trust Ltd. v. High Trees House Limited. ${ }^{23}$ In that case in September 1939 the plaintiff had leased for 99 years a block of flats to the defendant, a subsidiary, at an annual ground rent of $£ 2,500$. In January 1940 , the plaintiff, because of war conditions which had caused many vacancies in the flats, agreed in writing to reduce the rent to $£ 1,250$. No express time limit was set for the operation of this reduction and from 1940 to 1945 the defendant paid the reduced rent. By the beginning of 1945 the flats were again fully occupied and the receiver of the plaintiff company in September of 1945 claimed the full rent both retrospectively and for the future. He tested his claim by suing for rent at the original rate but only for the last two quarters of 1945. Judgment was given for the landlord on the ground that the special grounds on which the promise was made were no longer in existence. It is clear that this was so in both the quarters with respect to which rent at the original contract rent was claimed but it is clear that the judge's obiter opinion was that if a claim were made for rent at the original rate for the period prior to the beginning of 1945 it must fail.

In the course of his judgment for the landlord the learned Judge, Denning, J., uses language with regard to law and equity which it is thought would ring strange in the ears of students of Maitland. He says:

The decisions are a natural result of the fusion of law and equity. ${ }^{24}$

... and if the fusion of law and equity leads to this result so much the better.2s

At this time of day however when law and equity have been joined together for over seventy years, principles must be reconsidered in the light of their combined effect. ${ }^{20}$

Language to the same effect is found in other cases. In Solle v. Butcher, ${ }^{27}$ Denning, L.J., as he had become, said that much of the difficulty that had arisen in the case under review was due to the fact that "before the fusion of law and equity the courts of common law in order to do justice in the case in hand extended this doctrine of mistake beyond its proper limits".

In the Winter Garden Theatre Case ${ }^{23}$ Viscount Simon referring to

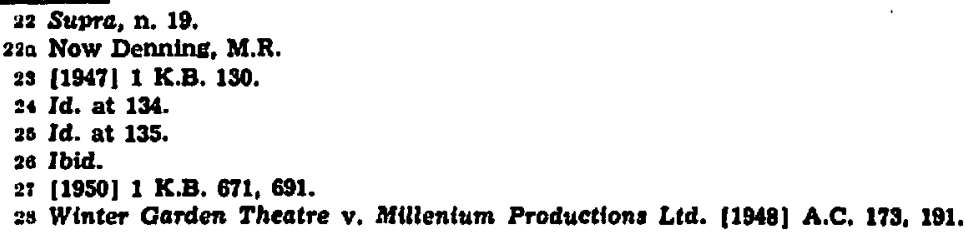


the case of Wood $v$. Leadbitter, ${ }^{29}$ an action by the plaintiff, who had paid for admission to a race track and was ejected, instituted at a time when the plaintiff had to elect whether to sue in tort for assault or in contract for damages said:

It is enough to say that at any rate since the fusion of law and equity no court in this country would refuse to a plaintiff in Woods situation the remedy for which he asked, and in my opinion the case should no longer be regarded as an authority.

Our problem is whether in these and other passages the word "fusion" means anything more than Hanbury means in his Modern Equity" where he tells us that the Judicature Act of 1873:

... fused together the three common law courts the Court of Chancery, the Court of Probate, the Divorce Court, and the Court of Admiralty.

or does "fusion" have the meaning in the statement:

The vast majority of practitioners must be prepared to meet point of equity, mixed up with points of law, in the same case, and they will be faced with the necessity of pooling together the sum of the resources of the two systems, and arriving at a composite result. Lord Justice Denning has for some time past, consistently stated ex cathedra that distinctions between law and equity are out of date, and talks always of the fusion of the systems themselves, and not only of the court in which, before 1875, they were separately administered, and since his example has now been followed from the Woolsack by Viscount Simonds, we may be justified in regarding the phrase 'fusion of law and equity' as a common form of speech. ${ }^{\mathrm{s}}$

No difficulty is experienced in accepting 'fusion of law and equity' as a form of speech if it means simply that the effect of the Judicature Acts anticipated by Maitland quoted at the beginning of this article has largely come about. But if it is meant that the principles have become fused and are uniformly applicable to any set of facts before the Court and that it is no longer necessary for a lawyer to know whether the remedy sought is a common law right or one which originally could be had only in a court of equity, then it would appear that those of us who have made Maitland's work the foundation of our equity learning will dissent.

To illustrate, would the Courts today, or can it be contemplated that they ever will, short of legislation, take any different view of the law applicable to the facts of Lavery v. Pursell ${ }^{32}$ than that there taken by Chitty, J.? In that case there was held to have been a written contract made for the sale and removal of a building. The subject of the sale was held to be an interest in land. The writing was insufficient to satisfy the Statute of Frauds in that the vendor's name was not specified. Delay occurred of sufficient length admittedly to disentitle the purchaser in an action brought by him for specific performance to that remedy. The purchaser relied on part performance by delivery of possession to him to support his alternative claim for damages. Chitty, J. dealt with this claim when he said:

Now this question of part performance resolves itself into this. Part performance was an equitable doctrine, and, putting it shortly, where there was performance under the contract it took the case out of the statute, but it was an equitable doctrine applied by the Courts of Equity, and it was applied in those cases where the Court would grant specific performance, for instance the case of a sale of land, but if, before the Judicature Act, the Court dismissed the bill

$2913 \mathrm{M} \&$ W. 838,153 E.R. 351.

30 8th ed. 1962, at 19.

31 Id. at 21 .

I2 39 Ch. D. 508. 
because it was not a case for specific performance, a Court of Law, when asked to give damages, the contract not being within the 4 th section, had no alternative but to refuse and to give judgment for the defendant in the action. But since the various amendments which have taken place in the law with regard to equitable doctrines, it has never been decided, so far as I am aware, that the equitable doctrine of part performance can be made use of for the purpose of obtaining damages on a contract at law. I considered the question carefully in In re Northumberland Avenue Hotel Company, and that went to the Court of Appeal. There it was impossible to give specific performance, because the subject-matter of the contract had come to an end; the Metropolitan Board of Works had entered, and the claimant-it was in a winding-up-could not claim opecific performance. It was in that case argued strenuously on behalf of the claimant that he was still entitled to obtain damages, and I held that he was not (although there had been part performance by entry), and my decision was, as I understand, affirmed by the Court of Appeal. ${ }^{33}$

It is curious to note that the case in the Court of Appeal of Brittain v. Rossiter ${ }^{34}$ was not cited. That was a case in which an injunction was sought to restrain the breach of a contract of service not to be performed within a year, which, though not in writing, had been partly performed. It was held that the doctrine of part performance was confined to actions relating to the sale of land and that the part performance could not be relied on to justify an award of damage for breach of contract.so

It is suggested that nothing that has been decided in any of the cases dealing with fusion would or ever could; short of legislation, have any bearing on decisions of the character of Lavery v. Pursell. In much of the literature bearing on this question legislation is regarded as the main, perhaps the only means of the fusion of the principles of the two systems. ${ }^{30}$

Dr. Hanbury in his Eighth Edition ${ }^{37}$ shows the effect of the 1925 legislation in England in fusing legal and equitable principles. He remarked in his Fifth Edith, ${ }^{38}$ and this appears from the pages referred to from the present Edition, that so far as concerns the law of property:

It might almost be said that the Property Acts have fused common law and equity into a new body of statute law.

It must be remembered that the possible adoption into the common law of equitable principles was a problem before the courts long before this century. It was clearly desired by Lord Mansfield who became Chief Justice of the Kings Bench in $\mathbf{1 7 5 6}$ holding that office for thirty years. The story of his attempts to fuse the two systems in the strict sense of the word is found in Holdsworth. ${ }^{39}$ He failed in his attempt, and the only important statutory provisions dealing with the relation of the two systems enacted prior to the Judicature Acts were The Common Law Procedure Act ${ }^{40}$ of 1854 and Lord Cairns' Act ${ }^{41}$ of 1858.

By Section 83 of the former Act it became lawful for the defendant:

-. In any cause in any of the superior courts in which, if judgment were obtained, he would be entitled to rellef against such judgment on equitable

93 Id. at 518.

s. 11 Q.B.D. 123.

33 See also James v. Thomas H. Kent \& Co. [1950] 2 All E.R. 1099.

so It is polnted out that the decislon of the Ontario Court of Appeal in De Gulto v. Boland [1958] D.L.R. (2d) 510 is consistent with that in Lavery v. Pursell.

37 Op. cit, supro n. 30, at 24-40.

38 Hanbury, Modem Equity (5th ed. 1949).

30 Holdsworth, op. cit. supta, n. 7, Vol. XII, at 583-589.

1017 \& 18 Vlet. c. 125 .

1121 \& 22 Viet. c. 27: See Alta. Judicalure Act R.S.A. 1955, c. 164, s. 34(7). 
grounds, to plead the facts which entitle him to such relief by way of defence, and the said courts are hereby empowered to receive such defence by way of plea; provided that such plea shall begin with the words "For defence on equitable grounds', or words to the like effect.

As seen however from Wodehouse v. Farebrother"2 this procedure could be followed only if the defendant would have been entitled to an absolute and perpetual injunction in equity. Lord Campbell, C.J. said:

It is not for us, sitting here judicially, to say how far it is desirable or expedient that equitable jurisdiction should be given to Courts of common law. We have only, looking at the language of the Legislature, to consider what equitable jurisdiction has actually been given to us, bearing in mind that, unless in as far as our power and our procedure have been altered by express enactment, or reasonable implication from what has been expressly enacted, they remain unchanged. Under the 83rd section of The Common Law Procedure Act, 1854, we are authorized to receive this defence by way of plea, if the facts pleaded would entitle the defendant to relief on equitable grounds in a Court of equity against a judgment obtained in this action in a Court of law, no equitable defence having been set up there.

... But, where the ground for equitable relief is not a complete bar to any proceedings upon the judgment, and if not, if offered by plea, a complete bar to the action, we are not furnished with any means of doing justice between the parties. We cannot enter into equities and cross equities; we should often be without means to determine what are the fit conditions on which relief should be given; no power is conferred upon us to pronounce a conditional judgment; no process is provided by which we could enforce performance of the condition; there are no writs of execution against person or goods adapted to such a judgment; and no one can conjecture what remedy it would give against the lands of the debtor. In short we think that a plea on equitable grounds is to prevail only where followed by a common law judgment, it will do complete and final justice between the parties. ${ }^{+3}$

It has of course been pointed out in many cases $^{44}$ that it is only in cases where a plaintiff is entitled to a decree of specific performance that the Court under Lord Cairns' Act has jurisdiction to award damages in lieu of such a decree.

To return then to the High Trees case one asks whether the decision extends unduly the principles laid down by the authorities relied on or can it be said that the decision is one where the judge properly makes law to cover gaps or legislates 'interstitially' to use Holmes' words."5

The learned Judge could find no consideration given to the lessor for the promise ${ }^{16}$ and both from the decision itself and from his article in the Modern Law Review ${ }^{47}$ it is clear that he thought that there had been neither the kind of representation ${ }^{48}$ nor the detriment to the tenant which would be necessary to raise a true estoppel either of the common law or equitable nature, the distinction between which seems to be without a difference since on the authorities there must in either case be a change of position by or detriment to the promisee before he can rely on the doctrine. In C.P.R. v. The King "' Lord Russell of Killowen for the Judicial Committee said:

Whether there can be any estoppel which is equitable as distinct from legal and whether 'equitable estoppel' is an accurate phrase their Lordships do not stop to inquire. The foundation upon which reposes the right of equity to

425 EN, \& Bl. 277, 119 E.R. 485.

13 Id. at E.R. 488-89. 14. See Lavery v. Pursell, supra n. 32.

45 Southern Pacific v. Jensen 244 U.S. 205, 221: quoted by Cardozo, The Nature of the Judicial Process (1st ed. 1921) at 69.

16 See supro $n .23$ at $133-4$.

17 Denning. Recent Development in the Doctrine of Consideration, (1952) 15 M.L.R. 1, 5. 18 See Jorden v. Money, (1854) 23 L.J. Ch. 865.

40 [1931] A.C. (P.C.(Can.)) 414, 429. 
intervene is either contract or the existence of some fact which the legal owner is estopped from denying.

This statement is made in relation to an interest in land but that it is generally applicable appears from Lord Selburn's judgment in Citzens' Bank of Louisiana v. First National Bank of New Orleans. ${ }^{50}$

Notwithstanding the foregoing, Denning, J. contends that there is authority in equity which will not allow the leśsor to go back on his work regardless of contract or detriment and that the Judicature Act requires that effect be given to the equity. He states his view that:

The law has not been standing still since Jorden $v$. Money. There has been a series of decisions over the last fifty years which, although they are said to be cases of estoppel are not really such. They are cases in which a promise was made which was intended to create legal relations and which, to the knowledge of the person making the promise, was going to be acted on by the person to whom it was made, and which was in fact so acted on. In such cases the courts have said that the promise must be honoured. The cases to which I particularly desire to refer are: Fenner v. Blake (1900) 1 Q.B. 226; In re Wickham (1917) 34 T.L.R. 1958, Re William Porter \& Co. Ltd. (1937) All E.R. 361, and Buttery v. Pickard (1946) W.N. 25. As I have said they are not cases of estoppel in the strict sense. They are really promises-promises intended to be binding, intended to be acted on, and in fact acted on. Jorden v. Money can be distinguished, because there the promisor made it clear that she did not intend to be legally bound, whereas in the cases to which I refer the proper inference was that the promisor did intend to be bound. In each case the court held the promise to be binding on the party making it, even though under the old common law it might be difficult to find any consideration for it. The courts have not gone so far as to give a cause of action in damages for the breach of such a promise, but they have refused to allow the party making it to act inconsistently with it. It is in that sense, and that sense only, that such a promise gives rise to an estoppel. The decislons are a natural result of the fusion of law and equity; for the cases of Hughes $v$. Metropolitan Ry. Co. (1877) 2 App. Cas. 439, 448, Birmingham and District Land Co. v. London \& North Western Ry. Co. (1888) 40 Ch.D. 268, 286, and Salisbury (Marquess) v. Gitmore (1942) 2 K.B. 38, 51, afford a sufficient basis for saying that a party would not be allowed in equity to go back on such a promise. In my opinion, the time has now come for the validity of such a promise to be recognized. The legal consequence, no doubt is that a promise to accept a smaller sum is discharge of a larger sum, if acted upon, is binding notwithstanding the absence of consideration; and if the fusion of law and equity leads to this result, so much the better. That aspect was not considered in Foakes v. Beer (1884) 9 App. Cas. 605.51

The result of this reasoning is that the judge finds it possible to avoid the authority both of the cases of Jorden v. Money," where the representation was as to the future as it was in the case before him, and Foakes v. Beer"s holding that a promise to accept a smaller sum in satisfaction of a larger is not binding. ${ }^{\text {it }}$

It is necessary then to inquire whether the cases relied on by Denning, J. really support the proposition that a promise made by a plaintiff without consideration moving to him and without detriment to the defendant is available to the latter as a defence to an action on the original cause with respect to which the promise had been given. But in another way, the question is whether there is to be found in the cases a type of estoppel which has been called promissory whereby a plaintiff is bound by a promise given by him and without consideration to him and with respect to which the defendant has suffered no detriment

s0 6 E. \& I. App. 352, 380; See also 15 Halsbury's Laws 223 (3d. ed. Simonds 1955 ).

52 Supra, n. 23 at 134 .

s2 Supra, n. 48 .

539 App. Cas. 605 .

64 See the Alta. Judicature Act R.S.A. 1955, c. 164, a. 3A(8) 
simply on the ground that the plaintiff intended the defendant to act on the promise and that he did so. In Halsbury's Laws'ss the author states the views of Denning, $\mathrm{J}$. on the question as expressed in the High Trees Case and modified or expanded by his remarks in Combe $v$. Combe. ${ }^{\text {b8 }}$ But the author also points to the questioning of the breadth of the statement of principle.

It is with all due deference suggested that there is to found in each of the cases cited on page 134 of the report the detriment that is necessary to bring them within the true principle which is perhaps best stated in the Birmingham ${ }^{37}$ case in these words:

The truth is that the proposition is wider than cases of forfeiture. It seems to me to amount to this that if persons who have contractural rights against others induce by their conduct those against whom they have such rights to believe that such rights will either not be enforced or will be kept in suspense or abeyance for some particular time those persons will not be allowed by a court of equity to enforce the rights until such time has elapsed without at all events placing the parties in the same position as they were before. That is the principle to be applied. I will not say it is not a principle that was recognized by courts of law as well as of equity: it is not necessary to consider how far it was always a principle of common law.

The words which I have italicized were relied on by Viscount Simonds in the Tool Metal ${ }^{38}$ case as showing the necessity of detriment in such cases and as a ground for questioning the accuracy of the principle stated in the High Trees case.

Is it true then that the cases relied on do show detriment?

In Hughes v. Metropolitan Ry. Co. ${ }^{\mathrm{s}}$ it is suggested that the detriment consisted in the fact that the tenant by reason of the negotiations for sale had proper ground for his belief that the time specified in the notice would not run during the period of the negotiations and that had he not been justified in that belief, he would have repaired within the time specified in the notice.

In the Birmingham"10 case the defendant had good ground to believe that its building covenant would not be insisted upon until the result of the Railway Company's action was known; otherwise it would have performed the covenant as to building.

The Gilmore ${ }^{i 1}$ case is in one of its aspects a similar case. The tenant is informed on applying for a new lease that the premises are to be torn down; for that reason he did not repair. The war broke out September 3,1939 ; the tenant vacated September 29, 1939, without having performed his covenant. The decision in the appeal is based by Lord Greene on Section 18 of the Landlord and Tenant Act of 1927, and he mentions only incidentally without deciding the point that the statement of the intention to demolish having been left uncorrected until after the determination of the lease the defendant could not be held liable in damages. At page 47 of the report the following statement appears

ss 15 Halsbury's Laws 175, Article 344 (3d ed. Slmonds 1955).

so [1951] 2 K.B. 215.

37 Birmingham and District Land Co. v. London and North Westem Rail Co. (1888) $10 \mathrm{Ch}$. D. 268.

s8 Tool Metal Manufacturing Co. Ltd. v. Tungsten Electric Co. Ltd. [1955] 2 All E.R. 657.

502 App. cas. 439.

Bo Supra, n. 57.

61 Sallsbury (Marquess) v. Gumore (1942) 2 K.B. 38. 
showing, it is suggested, that in the aspect of the case in which we are interested consideration was present. The statement is:

The first was that even if the intention of the plaintiffs had in fact been abandoned before September 29, the plaintiffs were precluded from 80 asserting since the statement which they had made as to the fate of the building in the letter of November 5, 1937 was left uncorrected until long after the termination of the lease and the defendant in reliance on that statement (as he said in evidence) refrained from doing the repairs.

In Fenner v. Blake ${ }^{62}$ the tenant desired to quit before the expiration of his term and obtained an oral promise from his landlord that he might do so. The landlord then sold the premises covenanting for possession on the date of surrender orally agreed on. The tenant having refused to deliver possession on the new date the landlord sued and succeeded. The case was regarded as an ordiniary one of estoppel. The consideration seems clearly to be present.

In re William Porter \& Co. Ltd. ${ }^{\text {ss }}$ the resolution of the directors to forego their fees was made to induce the company to carry on its operations which it did.

It has been suggested that detriment is difficult to find in the Tool Metal ${ }^{64}$ case but it is suggested that it is found in the fact that the licensees would base their trade polices on the promise that additional payments would not be demanded.

The cases subsequent to it do not support the broad proposition put forward in the High Trees case. It was considered in Combe v. Combe. ${ }^{a s}$ This is a case in which a wife commenced proceedings for divorce and obtained a decree nisi against her husband. The husband then promised to allow her $£ 100$ per annum free of tax as permanent maintenance. The wife did not in fact apply to the Divorce Court for maintenance, but this forbearance was not at the husband's request. The decree was made absolute. The annual payments were never made and ultimately the wife sued the husband on his promise to make them.

Byrne, J. relying on the High Trees case and Robertson v. Minister of Pensions $^{\text {ni }}$ gave judgment for the wife. The Court of Appeal reversed this judgment, and Denning, L.J., as he had become, explains his High Trees decision. He seems to have his own doubts about its validity because he opens his discussion of it with the words:

Much as I am inclined to favour the principle of the High Trees Case it is important that it should not be stretched too far lest it should be endangered.

He then proceeds to state his view that the facts of the High Trees case would give the tenant no cause of action, and that unless the wife in the Combe Case could show consideration for the husband's promise, she could not sue on it.

Birkett, L.J. expresses no opinion either way on the soundness of the High Trees decision. He is content to say first that the trial judge was right in finding that there was no consideration for the promise, and secondly that the principle stated in both the High Trees case and in Robertson v. Minister of Pensions is that the doctrine relied on may be

62 [1900] 1 K.B. 426.

C3 [1987] z All E.R. 361.

64 Supra, n. 58.

os Supra, n. 56.

o0 [194B] 2 All E.R. 767; [1049] 1. K.B. 277. 
used only as a shield and not as a sword. Asquith, L.J. expresses no opinion on the soundness of the High Trees decision.

Some slight indication of the possible fate of the High Trees decision if similar facts reach the House of Lords is indicated by the remark of Simonds, L.C. in the Tool Metal case ${ }^{\text {"I }}$ in 1955 where after emphasizing the words "without at all events placing the parties in the same position as they were before" found in the last two lines of the passage from the Birmingham Case quoted above, he says:

These last words are important, for they emphasize that the gist of the equity lies in the fact that one party has by his conduct led the other to alter his position. I lay stress on this, because I would not have it supposed, particularly in commercial transactions, that mere acts of indulgence are apt to create rights, and I do not wish to lend the authority of this House to the statement of the principle which is to be found in Combe v. Combe (1951, 1 All E.R. at p. 770) and may well be far too widely stated.

In determining the question in the last analysis the court will require to consider the distinction drawn by Lord Denning in his article in the Modern Law Review ${ }^{\text {ng }}$ between a promise and other conduct of a plaintiff. He there takes the position that in the case of a promise a man should keep his word, and detriment suffered by the promisee is not essential; but the case might be otherwise when only conduct was in question.

Reference may be made to the New Zealand case of $P$. v. $P .^{.0}$ In that case a husband and wife had separated, and by the deed of separation the husband agreed to pay a monthly sum to the wife. Later the parties were divorced and the court ordered the husband to pay to the wife one shilling a year as maintenance. The wife was insane; and her administrator, the Public Trustee, told the husband that the court order cancelled the provisions of the separation deed. The husband accordingly paid no further instalments under it. More than four years later the Public Trustee found that he had wrongly interpreted the effect of the court order and sued for the monthly instalments. The husband pleaded the principle set out in the High Trees case and in Combe v. Combe. The action was dismissed, but the significance from our present point of view of this and the Tool Metal Case is that in each there was clear detriment to the defendant.

The conclusion that it is suggested should be drawn from the above examination of only a small part of the literature on the subject is that Maitland's views of the place of Equity in English law are still valid; that nothing has occurred to disturb the soundness of decisions of the nature of Lavery $v$. Pursellio and that if fusion of the principles of Equity, as distinct from its procedure, and those of the common law are to be brought about it can be only through legislation.

or Supra, n. 58 at 660 .

os Loc. cit. supra n. 47 , at 5.

$O D$ [1957] N.2.L.R. 854; See Comment in (1958) 21 M.L.R. 185.

To Supre n. 36. 